\title{
PENGEMBANGAN PERANGKAT PEMBELAJARAN MATA KULIAH IPA MI BERBASIS NILAI MORAL
}

\author{
Alwan Mahsul \\ Dosen Jurusan Tadris IPA Biologi FITK IAIN Mataram
}

\begin{abstract}
Abstrak
Upaya peningkatan sensitivitas moral dalam pendidikan membutuhkan pengembangan model, metode, dan strategi pembelajaran inovatif. Salah satu model pembelajaran yang mengintegrasikan nilai-nilai moral di dalam kegiatan pembelajaran adalah Model Pembelajaran kooperatif. Dalam model ini banyak-aspek-aspek moral yang dapat dikembangkan dalam proses pembelajaran, terlebih Ilmu Pengetahuan Alam (IPA) merupakan mata kuliah yang memberikan banyak kesempatan untuk mengungkapkan nilai-nila, sehingga model pembelajaran koopertif ini dapat digunakan untuk mengembangkan aspek-aspek moral yang direncanakan guru untuk ditumbuhkembangkan dalam kelas. Penggunaan pendekatan pengungkapan nilai-nilai dalam sains merupakan cara untuk membuat pengajaran sains lebih nyata dan lebih berarti, memberikan perhatian kepada sains, dan menolong para mahasiswa untuk mengintegrasikan fikiran, perasaan, serta tindakan mereka dalam perkembangannya menjadi orang dewasa. Penelitian ini dilakukan dengan tujuan untuk: (1) Mengembangkan perangkat pembelajaran, (2) Mendeskripsikan kualitas perangkat pembelajaran, (3) Mendeskripsikan efektifitas penerapan perangkat pembelajaran. Perangkat pembelajaran yang dimaksud adalah perangkat pembelajaran berbasis nilai moral mata kuliah IPA MI I. Penelitian ini merupakan penelitian pengembangan, karena mengembangkan perangkat pembelajaran. Pengembangan perangkat pembelajaran dalam penelitian ini, mengikuti model pengembangan Kemp.. Teknik analisis data yang digunakan adalah statistik deskriptif.
\end{abstract}

Keywords: Hemogobin levels, Factors Affecting Hemoglobin Levels, Junior High School Student 


\section{PENDAHULUAN}

IPA sebagai bagian dari sains merupakan deretan konsep dan skema konseptual yang berhubungan satu sama lain, dan yang tumbuh sebagai hasil eksperimentasi dan observasi serta berguna untuk dieksperimentasikan lebih lanjut. IPA merupakan kesatuan produk, proes dan sikap, sehingga tujuan pembelajaran IPA harus mengacu pada tiga aspek esensial, yaitu: membangun (1) pengetahuan berupa pemahaman, konsep, hukum dan teori serta penerapannya; (2) kemampuan melakukan proses anatara lain pengukuran, percobaan, bernalar melalui diskusi; (3) sikap keilmuan, anatara lain kecenderungan keilmuan, berfikir kritis, berfikir analitis, perhatian pada masalah-masalah sains, penghargaan pada hal-hal yang bersifat sains. Berdasarkan tujuan tersebut maka pembelajaran mata kuliah IPA MI I harus mampu menberikan kesempatan yang luas kepada mahasiswa untuk mengembangkan potensinya secara utuh melalui kegiatan olah fikir, olah rasa, olah hati dan olahraga.

Kenyataan di lapangan menunjukkan bahwa kegiatan pembelajaran IPA belum memberikan kesempatan yang luas kepada siswa/mahasiswa untuk mengembangkan potensinya secara utuh. Berdasarkan pengalaman empiris peneliti pembelajaran mata kuliah IPA 1 selama ini lebih kepada pencapaian hasil belajar di dalam ranah kognitif dan psikomotor sedangkan ranah afektif masih kurang mendapat perhatian. Di sisi lain berdasarkan telaah sampel Satuan Acara Perkuliahan (SAP) mata kuliah IPA MI I dan pembelajaran IPA di Jurusan PGMI FITK IAIN Mataram diperoleh informasi bahwa dosen belum banyak mencantumkan hasil belajar berupa nilai-niali moral, spiritual dan humaniora, dosen masih kurang mengajak mahasiswa melakukan pemaknaan terhadap konsep-konsep yang diberikan, tidak mengintegrasikan nilai-nilai moral, agama dan humaniora di dalam kegiatan pembelajarannya.

Upaya peningkatan sensitivitas moral dalam pendidikan membutuhkan pengembangan model, metode, dan strategi pembelajaran inovatif.Salah satu model pembelajaran yang mengintegrasikan nilai-nilai moral di dalam kegiatan pembelajaran adalah Model Pembelajaran kooperatif. 
Mengacu pada model pembelajaran kooperatif, peneliti akan mengembangkan perangkat yang sesuai untuk mata kuliah IPA MI I pada pokok bahasan Ekologi di Jurusan PGMI FITK IAIN Mataram. Selain komptensi akademik, indikator yang akan diukur adalah kepekaan (sensitivitas) moral mahasiswa dalam proses pembelajaran. Berdasarkan uraian tersebut penelitian yang akan dilakukan berjudul "Pengembangan Perangkat Pembelajaran mata kuliah IPA MI 1 Berbasis Nilai-nilai Moral"

\section{METODE PENELITIAN}

Penelitian ini termasuk penelitian pengembangan yaitu mengembangkan perangkat pembelajaran. Penelitian pengembangan ini dilaksanakan untuk menghasilkan perangkat pembelajaran yang selanjutnya akan diujicobakan di kelas. Perangkat pembelajaran yang dikembangkan adalah Satuan Acara Perkuliahan, Buku Ajar Mahasiswa, Lembar Kegiatan Mahasiswa, dan Instrumen Penilaian nilai-nilai moral. Yang akan menjadi subjek dalam penelitian ini adalah perangkat pembelajaran yang dikembangkan, sedangkan yang menjadi subjek uji coba perangkat pembelajaran adalah: mahasiswa jurusan PGMI FITK IAIN Mataram. Uji coba untuk mengembangkan perangkan pembelajaran berbasis nilai moral akan dilaksanakan pada saat perkuliahan mata kuliah IPA MI di Jurusan PGMI FITK IAIN Mataram.

\section{Prosedur Pengembangan}

Proses pengembangan perangkat akan dilakukan di dalam tiga tahap, yaitu penetapan (define), perancanagan (design), dan pengembangan (develop). Pengembangan perangkat dalam penelitian yang dilakukan akan mengikuti model The Four D yang dikembangkan oleh Thiagarajan, Semmel (1974).

Tahap pengembangan bertujuan untuk menghasilkan perangkat pembelajaran yang telah direvisi berdasarkan masukan dari validator. Tahap ini meliputi: validasi oleh ahli, revisi 1 , uji coba 1 , revisi 2 , uji coba 2 , analisis, revisi ketiga, dan perangkat pembelajaran. 
a. Validasi perangkat akan dilakukan oleh tiga pakar yang kompeten.

b. Dalam uji coba 1 (terbatas hanya 20 orang mahasiswa) dan uji coba 2 sebanyak 20 orang mahasiswa juga.

\section{InstrumenPenelitian}

Instrumen yang akan dikembangkan dan digunakan di dalam penelitian ini adalah sebagai berikut:

a. Lembar Penilaian Kualitas Perangkat Pembelajaran, meliputi:

1) Lembar validasi perangkat

Lembar validitas perangkat akan digunakan sebagai acuan untuk menilai kelayakan komponen perangkat yang dikembangkan.

2) Angket tingkat kesulitan Buku Ajar Mahasiswa

Angket ini akan berbentuk kolom pengisian jumlah kalimat dalam buku ajar yang tidak dapat difahami oleh mahasiswa dan jumlah keseluruhan kalimat.

\section{b. Instrumen Penilaian Proses Pembelajaran}

Instrumen ini akan digunakan untuk mengetahui tingkat kesesuaian pelaksanaan pembelajaran dengan proses pembelajaran yang ada di dalam sintaks Model Pembelajaran Pemaknaan yang dirancang di dalam SAP.

\section{c. Lembar Observasi sikap moral}

Merupakan instrument yang akan digunakan untuk memperoleh data mengenai tingkat kepekaan mahasiswa di dalam menangkap makna pada gejala yang ditemukan dan menghubungkannya dengan nilai moral atau contoh sikap hidup. Instrumennya berbentuk pilihan ganda. Tingkat sensitivitas berdasarkan rubrik sensitivitas moral yang akan dikembangkan oleh peneliti berdasarkan teori instrument pengukuran nilai moral (Exploring values instrument) dalam bukuHow to Teach about Value: an Analytic Approach. 


\section{d. Angket Respon Mahasiswa}

Angket respon mahasiswa akan digunakan untuk mengukur pendapat dan tanggapan mahasiswa terhadap komponen kegiatan pembelajaran meliputi: materi/isi pelajaran, format buku ajar, LKM, latihan ketrampilan proses, suasana belajar, cara dosen mengajar, proses pemaknaan, dan tes hasil belajar. Angket yang digunakan adalah ARCS

\section{Teknik Analisa Data}

Data yang akan dikumpulkan dianalisis menggunakan statistik diskriptif kualitatif. Hasil analisis kuantitatif kemudian dideskripsikan secara kualitatif.

\section{a. Analisis Hasil Validasi Perangkat Pembelajaran}

Data hsil validasi perangkat pembelajaran akan di analisis dengan cara menghitung rata-rata skor penilaian oleh 3 orang validator interval skor 1 sampai dengan 5 , dengan ketentuan kriteria sebagai berikut:1 = tidak baik, 2 = kurang baik, 3 =cukup baik, 4 baik, 5 sangat baik.

\section{b. Analisis Tingkat Kesulitan Buku Ajar Siswa}

Kriteria persentase tingkat kesulitan buku ajar siswa yang diperoleh adalah sebagai berikut:

1. $0,0 \%-20,9 \%=$ tingkat kesulitan sangat rendah/sangat mudah dipahami.

2. $21,0 \%-40,9 \%=$ tingkat kesulitan $\mathrm{rendah} / \mathrm{mudah}$ dipahami.

3. $41,0 \%-59,9 \%=$ tingkat kesulitan sedang/kurang dapat dipahami.

4. $60,0 \%-79,9 \%=$ tingkat kesulitan sulit/sulit dipahami.

5. $80,0-100,0 \%=$ tingkat kesulitan sangat sulit/sangat sulit dipahami

\section{c. Analisis Keterlaksanaan Satuan Acara Perkuliahan (SAP)}

Keterlaksanaan Acara Perkuliahan akan dianalisis dengan cara menghitung rata-rata skor penilaian oleh dua orang 
pengamat menggunakan interval skor 1 sampai dengan 4, dengan ketentuan kriteria sebagai berikut: 1=sangat baik, 2=kurang baik, 3=baik, 4=sangat baik.

\section{d. Analisis Sensitivitas Moral Mahasiswa}

Data hasil pengamatan aktivitas siswa, selama KBM berlangsung dianalisis dengan menggunakan persentase (\%), yakni banyaknya frekuensi aktivitas dibagi dengan seluruh frekuensi aktivitas, dikali 100\%.

\section{e. Analisis Tes Hasil Belajar Mahasiswa}

Hasil belajar mahasiswa dianalisis menggunakan Penilaian Acuan Patokan (PAP) dengan rumus sebagai berikut:

$$
\text { Nilai }=\frac{\text { skor yang tiperoleh }}{\text { skor maksimum }} \times 100 \%
$$

Selanjutnya hasil perhitungan dimasukkan ke dalam pedoman konversi untuk menentukan tingkat kelulusan mahasiswa menggunakan Tabel di bawah ini: Arikunto (1998), yaitu: $76 \%$ - $100 \%=$ sangat tinggi, $56 \%-75$ $\%=$ tinggi, $40 \%$ - $55 \%=$ cukup tinggi, Kurang dari 40 $\%=$ rendah.

\section{HASIL PENGEMBANGAN PRODUK}

Selama kegiatan Pembelajaran Ujicoba I dan II yang merupakan tahap pertama dan tahap kedua dari rangkaian penelitian ini, aspek-aspek yang menggambarkan efektivitas penerapan perangkat pembelajaran berbasis nilai-nilai moral yang diajarkan dengan model pembelajaran koperatif tipe STAD dicatat dan dianalisis. Hasil temuan selama kegiatan Ujicoba I dan II, seperti yang telah dipaparkan pada Bab IV akan didiskusikan pada bagian ini. Hasil temuan dan diskusi ini, merupakan gambaran secara utuh dan menyeluruh tentang kualitas perangkat pembelajaran, dan efektivitas penerapan perangkat 
pembelajaran yang berorientasi metode bermain peran yang diajarkan dengan model pembelajaran kooperatif tipe STAD bahan kajian gerakan Bumi dan Bulan.

\section{Hasil Pengembangan Perangkat Pembelajaran}

Perangkat pembelajaran yang berhasil dikembangkan dalam penelitian ini adalah Perangkat pembelajaran yang berbasis nilai-nilai moral yang diajarkan dengan model pembelajaran koopertif tipe STAD, yang meliputi Satuan Acara Perkuliahan.Lembar Kegiatan Mahasiswa, Buku Ajar Mahasiswa, dan Tes Hasil Belajar Mahasiswa.

\section{a. Satuan Acara Perkuliahan (SAP)}

Pada saat proses pengembangannya SAP yang telah dikembangkan telah direvisi oleh tiga orang validator. Hasil revisi SAP oleh 3 orang validator secara ringkas adalah: Menyesuaikan indikator dengan tujuan pembelajaran, menentukan tujuan produk dan tujuan kinerja, menentukan tujuan yang harus dicapai tiap tatap muka, materi yang dicantumkan pada SAP merupakan garis besar materi pembelajaran, urutan langkah pembelajaran pada kegiatan inti perlu lebih spesifik, menyederhanakan rancangan kegiatan bermain peran sesuai tingkat perkembangan anak, Tata bahasa disesuaikan dengan ejaan yang telah disempurnakan.

\section{b. Lembar kerja mahasiswa (LKM)}

LKM yang dikembangkan memiliki kelebihan misalnya dari segi isi antara lainpetujuk dan arahan pada LKM dirancang secara sistematis, mudah, dan jelas, sehingga mahasiswa mudah memahami maksud dan perintah yang ada pada LKM . LKM/LKS merupakan salah satu bahan ajar sebagai sumber belajar yang membawa pesan untuk tujuan pengajaran dan lembar kegiatan yang diupayakan untuk dikuasai oleh siswa. Selain itu perintahperintah dan pesan-pesan pada LKM bersifat analisis materi yang ada pada buku ajar, dan bukan semata memindahkan materi yang ada di buku ajar mahasiswa, substansi isi disesuaikan dengan kurikulum yang berlaku 
sehingga tidak menyimpang dari materi yang dipelajari mahasiswa.

Setelah mendapatkan revisi dari 3 orang validator, LKM yang telah dikembang dapat dipergunkakan sebagai perangkat pembelajaran dan berdasarkan penilaian 3 orang validator, LKM yang telah dikembangkan memiliki kualitas baik dan dapat dipergunakan dengan sedikit revisi. Adapun hasil revisi oleh validator adalah: Butir pertanyaan pada LKM harus bersifat analisis dari buku ajar mahasiswa, bukan semata-mata jawabannya disalin dari buku ajar mahasiswa, perlu diperjelas maksud pertanyaan, atau tugas-tugas yang harus dilakukan siswa, dan memperbaiki tata bahafa sesuai ejaan yang telah disempurnakan.

\section{c. Buku Ajar Mahasiswa (BAM)}

Buku ajar mahasiswayang dikembangkan merupakan buku utama. Ketidaksesuaian konsep, prinsip, fakta, dan contoh-contoh pada buku yang biasa digunakan oleh dosen untuk mengajarkan IPA disempurnakan dengan mengadopsi dari sumber-sumber lain yang dianggap relevan. Buku lain yang digunakan oleh peneliti untuk menyempurnakan buku mahasiswa adalah seperti yang tercantum pada bagian daftar pustaka.

Buku ajar mahasiswa yang dikembangkan disesuaikan dengan kebutuhan anak didik pada usia tertentu dan pada lingkungan tertentu pula. Hal ini sesuai seperti yang dikatakan Arikunto dalam Agustiningsih bahwa BAM adalah salah satu bahan ajar yang merupakan unsur inti dalam kegiatan belajar mengajar yang harus disesuaikan dengan kebutuhan anak didik pada usia tertentu dan pada lingkungan tertentu pula.

Pada saat proses pengembangannya BAM yang dikembangkan telah direvisi dan diberikan penilaian oleh tiga orang validator. Hasil revisi oleh validator secara ringkas adalah: membuat kata kunci pada setiap sub kajian, tujuan pembelajaran pada buku ajar mahasiswa 
tidak perlu dicantumkan secara kaku, gambar-gmabar yang tercantum pada buku ajar mahasiswa diperbesar dan diperjelas, memperbaiki tata bahasa, seperti penempatan tanda baca, dan kesesuaian ejaan dengan ejaan bahasa baku. Penilaian umum tiga orang validator bahwa buku ajar mahasiswa yang telah dikembangkan memiliki kualitas baik dan dapat dipergunkan sebagai perangkat pembelajaran.

\section{d. Tes Hasil Belajar (THB)}

Tes hasil belajar yang dikembangkan adalah tes hasil belajar yang mengacu pada tujuan. THB yang dikembangkan merupakan tes untuk mengukur hasil belajar mahasiswa. THB yang dikembangkan dalam pelelitian ini berupa tes Essy yang terdiri dari 5 butir soal. Dalam prosesnya pengembanaganya THB telah mendapatkan revisi dari tiga orang validator. Hasil revisi tersebut secara ringkas adalah: Ketidaksesuaian tujuan dengan tingkat kognitif, yaitu butir soal nomor: 2 dan 3, bahasa yang digunakan dapat menimbulkan penapsiran ganda yaitu yaitu soal nomor 4 .

\section{Kualitas Perangkat Pembelajaran}

Kualitas perangkat pembelajaran adalah tingkat kelayakan perangkat pembelajaran yang dapat dilihat dari hasil validasi perangkat pembelajaran dan tingkat kesulitan buku ajar siswa. Validasi perangkat pembelajaran dan tingkat kesulitan buku ajar mahasiswadapat diuraikan sebagi berikut:

\section{a. Validitas Perangkat Pembelajaran.}

Validitas perangkat pembelajaran adalah kelayakan perangkat pembelajaran yang meliputi kelayakan SAP, BAM, LKM , dan THB yang mencakup komponen isi, format, bahasa. Kelayakan perangkat pembelajaran ini telah divalidasi oleh tiga orang pakar. Hasil validasi perangkat pembelajaran akan diuraikan sebagi berikut: 


\section{1) Validasi Satuan acara perkuliahan (SAP )}

Berdasarkan hasil analisis data validasi SAP oleh 3 orang validator yang meliputi tiga kategori yaitu format, bahasa, dan isi, diperoleh rentang skor rata-rata antara 3.8 sampai 4.4. Dengan demikian dapat disimpulkan bahwa SAP yang telah dikembangkan memiliki kualitas baik, oleh karena itu dapat dipergunakan sebagai perangkat pembelajaran.

\section{2) Validasi Lembar Kerja Mahasiswa (LKM)}

Berdasarkan hasil analisis data hasil penilaian yang diberikan oleh 3 orang validator, yang meliputi tiga kategori yaitu format, bahasa, dan isi, diperoleh rentang skor rata-rata antara 3.8 sampai 3.9. Dengan demikian dapat disimpulkan bahwa LKM yang telah dikembangkan memiliki kualitas baik, dan oleh karena itu dapat dipergunakan sebagai perangkat pembelajaran.

\section{3) Validasi Buku Ajar Mahasiswa(BAM)}

Berdasarkan analisis data hasil validasi Buku ajar mahasiswaoleh tiga orang validator yang meliputi tiga kategori yaitu format/penyajian, bahasa, dan isi diperoleh rentang skor rata-rata komponen yang dinilai berkisar antara 3.9 sampai 4.3.Dengan demikian dapat disimpulkan bahwa buku ajar mahasiswayang telah dikembangkan memiliki kualitas baik, dan oleh karena itu, dapat dipergunakan sebagi perangkat pembelajaran.

\section{4) Validasi Tes Hasil Belajar (THB)}

Berdasarkan hasil validasi Tes Hasil Belajar (THB) oleh tiga orang validator, yang meliputi tiga kategori yaitu validitas isi, bahasa, dan penulisan soal. Hasil penilaian yang diberikan oleh 3 orang validator adalah: Validator 1 memberikan penilaian untuk komponen validitas isi, dari 5 soal semuanya valid. Untuk komponen bahasa dan penulisan dari 5 soal semuanya dapat dipergunaan. Kesimpulan validator 1 adalah dari 54 soal tanpa revisi dan satu soal revisi kecil. Validator 2 memberikan penilaian untuk komponen validitas isi dari 5 soal semuanya valid. Untuk komponen bahasa dan penulisan 
soal semuanya dapat dipegunaan. Kesimpulan validator 2, dari 5 soal 4 soal tanpa revisi dan 1 soal revisi kecil. Validator 3 memberikan penilaian, untuk komponen validitas isi dari 5 soal semuanya valid. Untuk komponen bahasa dan penulisan soal semuanya dapat dipergunaan. Kesimpulan validator 3, dari 5 soal semuanaya tanpa revisi.

\section{b. Tingkat Kesulitan Buku Ajar Mahasiswa(BAM)}

Tingkat kesulitan Buku ajar mahasiswaadalah tingkat pemahaman siswa terhadap BAM yang telah dikembangkan. Untuk memperoleh data tentang tingkat kesulitan Buku Ajar Siswa, diambil 5 orang siswa sebagai sampel. Siswa yang dijadikan sampel diminta membaca BAM yang telah dikembangkan dan menandai kalimat yang tidak dimengertinya. Selanjutnya BAM diukur tingkat kesulitannya dengan mempersentasikan banyaknya kalimat yang kurang dimengerti siswa dibagi jumlah kalimat yang ada dikalikan $100 \%$.

Berdasarkan hasil analisis persentase tingkat kesulitian BAM tiap sub bahan kajian dapat diketahui bahwa rata-rata persentase tingkat kesulitan BAM berkisar antara antara $0,0 \%-10 . \%$ Hal ini menunjukkan bahwa tingkat kesulitan BAM sangat rendah atau BAM sangat mudah dipahami oleh siswa, ini disebabkan karena BAM dikembangkan sesuai kebutuhan anak. Hal ini sesuai dengan pendapat Djamarah dan Zain dalam Agustiningsih yang menyatakan bahwa, dalam menyampaikan bahan pelajaran harus sesuai dengan perkembangan bahasa dan kebutuhan anak didik.Oleh karena BAM yang dikembangkan memiliki tingkat kesulitan sangat rendah maka, BAM dapat digunakan sebagai perangkat pembelajaran.

\section{Efektivitas Penerapan Perangkat Pembelajaran}

Untuk mengetahui efektivitas penerapan perangkat pembelajaran yang telah dikembangkan maka, dilakukan penerapan perangkat pembelajaran pada siswa yang dijadikan subjek Ujicoba perangkat pembelajaran. Efektivitas penerapan perangkat pembelajaran merupakan ukuran 
keberhasilan penerapan suatu perangkat pembelajaran.Dalam penelitian ini perangkat pembelajaran yang diuji efektivitasnya adalah perangkat pembelajaran berbasis nilainilai moral yang diajarkan dengan model pembelajaran kooperatif tipe STAD.

Efektivitas penerapan perangkat pembelajaran dalam penelitian ini dilihat dari aspek keterlaksanaan satuan acara perkuliahan, frekwensi nilai-nilai moral yang muncul selama $\mathrm{KBM}$, respon mahasiswa selama $\mathrm{KBM}$, dan hasil belajar mahasiswa setelah mengikuti pembelajaran.

\section{Keterlaksanaan Satuan Acara Perkuliahan (SAP)}

Keterlaksanaan SAP meliputi dua komponen yaitu Pengelolaan KBM yang terdiri dari kegitan pendahuluan, kegitan inti, dan kegitan penutup dan Suasana kelas yang meliputi antusiaisme siswa dan antusiaisme dosen, pengelolaan waktu, dan kesesuaian KBM dengan sekenario yang telah dirancang.

Hasil observasi keterlaksanaan SAP seperti yang terlihat pada Tabel 4.7, menunjukkan bahwa, keterlaksanaan SAP memiliki skor yang berkisar antara 3.4 sampai 4.0. Hal ini menunjukkan, keseluruhan aspek yang diamati dalam keterlaksanaan Satuan acara perkuliahan yang meliputi pengamatan KBM dan suasana kelas adalah terlaksana dengan sangat baik kecuali pada kegiatan inti untuk Ujicoba I dilaksanakan dengan katagori baik. Keterlaksanaan SAPini didukung oleh ketersediaan perangkat pembelajaran yang dikembangkan oleh peneliti, seperti SAP, LKM , BAM, dan THB. Perangkat pembelajaran tersebut sangat menentukan keterlaksanaan SAP sesuai model pembelajaran yang diterapkan. Hal ini sesuai dengan pendapatnya Nur yang menyatakan bahwa salah satu faktor yang mempengaruhi kualitas pembelajaran adalah tersedianya perangkat pembelajaran yang disertai dengan komitmen yang tinggi untuk menggunakannya dalam setiap pembelajaran.

Terlaksananya KBM karena dosen dalam proses pembelajaran memiliki komitmen yang tinggi untuk 
menggunakan perangkat pembelajaran yang telah dikembangkan. Suatu program pembelajaran akan dapat mencapai hasil seperti yang diharapkan apabila direncanakan dengan baik, semua komponen pengajaran harus diperankan secara optimal. Hal ini sesuai dengan pendapatnya Sagala yang mengatakan bahwa semua komponen pengajaran harus diperankan secara optimal guna mencapai tujuan pengajaran yang telah dirumuskan sebelum pengajaran dilaksanakan.

Pembelajaran Ilmu Pengetahan Alam (IPA) pada jenjang Sekolah Dasar diharapkan akan dapat mengembangkan kompetensi siswa yang meliputi: 1) bersikap ilmiah, 2) menterjemahkan sifat-sifat dan perilaku alam dan lingkungan sekitar, 3) memahami proses pembentukan ilmu pengetahuan dan melakukan inkuiri ilmiah melalui pengamatanSiswa.asekolah dasar diharapkan mulai mampu mengembangkan kemampuan berpikir kritis, kreatif dan memiliki inisiatif dalam menghadapi masalahmasalah yang muncul sebagai dampak perkembangan ilmu pengetahuan dan teknologi (Ibrahim, dalam Khadijah). Oleh karena itu, dalam mempelajari IPA siswa perlu dibantu untuk dapat meningkatkan sejumlah keterampilan atau bekerja melalui metode ilmiah sederhana guna memahami masalahmasalah IPA terutama yang berhubungan dengan kehidupan sehari-harinya secara langsung maupun tidak langsung

Agar proses pembelajaran dapat terlaksana dengan baik maka, dosen harus merancang pembelajaran yang akan dilaksanakan terutama untuk menentukan pendekatan pembelajaran yang sesuai dengan karakteristik materi yang akan diajarkan dan membuat indikator untuk mengetahui apakah pembelajaran yang telah dirancang dapat berjalan dengan efektif atau tidak. Pembelajaran yang dirancang oleh dosen hendaknya melibatkan siswa secara penuh agar siswa dapat mengembangkan potensinya dengan maksimal. Dosen dituntut memiliki kemampuan untuk melibatkan peserta didik secara aktif selama pembelajaran dan menciptakan suasana yang menunjang agar tercapai tujuan pembelajaran, yang sesuai dengan kompetensi yang dimilikinya. Hal senada 
diungkapkan oleh Mulyanigsih. dalam penelitiannya tentang pengembangan penuntun belajar menemukan bahwa siswa SD menyenangi pembelajaran yang melibatkan siswa dalam bentuk bekerja mandiri, diskusi, maupun praktek. Instrumen yang digunakan untuk mengamati keterlaksanaan SAP dapat dipercaya karena, memiliki reabilitas dengan katagori baik. Hal ini terlihat dari persentase realibilitas rata-rata yang dimiliki instrumen di atas $75 \%$ baik pada Ujicoba I dan II. Menurut Borich (1994) suatu instrumen dikategorikan baik dan dapat digunakan untuk kegiatan pengamatan bila reliabilitasnya lebih besar atau sama dengan 75\%.

\section{Nilai moral yang muncul Selama KBM}

Pengamatan frekwensi selama KBM Frekuensi nilai-nilai moral yang muncul selama KBM pada penerapan perangkat pembelajaran berbasis nilai moral pokok bahasan Ekologi pada mahasiswa jurusan PGMI FITK IAIN Mataram dilakukan oleh 2 orang pengamat dengan lembar pengamatan nili moral yang muncul selama KBM. Nilai moral yang diamati adalah yang diamatai adalah: 1) Taat pada ajaran agam, 2) rasa ingin tau, 3) Jujur, 4) ketelitian dan ketekunan, 5) toleransi, 6) tanggung jawab, 7) keterampilan berkomunikasi, 8) peduli terhadap lingkungan.

Hasil pengamatan nilai-nilai moral mahasiswa, seperti yang terlihat pada Tabel 4.9, menunjukkan bahwa dari 8 macam nili-nilai moral yang diamati, terlihat bahwa frekwensi nilai-nilai moral mahasiswa yang muncul adalah merata dengan kata lain nilai-nilai moral yang direncanakan semuanya mucul dalam proses pembelajaran. Skor nilai moral yang muncul berkisar anatara berkisar antara $11.00 \%$ Sampai 13.6 dari dari 8 nilai moral yang diamatai . Frekwensi nilai moral nilai moral yang memiliki skor tertinggi toleransi dan ketelitian dan ketekunan pada siklus II

Instrumen yang digunakan untuk mengamati aktivitas siswa, dapat dipercaya karena memiliki reabilitas dengan katagori baik. Hal ini terlihat dari persentase realibilitas ratarata yang dimiliki instrumen di atas $75 \%$ baik pada Ujicoba I 
dan II. Menurut Borich suatu instrumen dikategorikan baik dan dapat digunakan untuk kegiatan pengamatan bila reliabilitasnya lebih besar atau sama dengan $75 \%$. Peningkatkan keberhasilan peserta didik dalam rangka membentuk mental, moral, pembelajaran berbasis moral efiktif sebagi model pembelajaran untuk mencapai nilai-nilai spriritul dan sosial. Zuhriah mengatakan dalam rangka membentuk mental, moralitas, spiritual, personal, dan sosial pendidikan budi pekerti merupakan cara paling efektif untuk tujuan tersebut

\section{Hasil Belajar Mahasiswa}

Tes hasil belajar digunakan untuk mengetahui tingkat penguasaan mahasiswa terhadap materi pelajaran yang diukur dengan Penilaian Acuan Patokan (PAP). Pembelajaran yang menerapkan perangkat berbasis nilai moral pada Ujicoba I, membuktikan bahwa 7 dari 20 orang mahasiswa memperoleh nilai A (60\%), nilai "B" dengan kategori tinggi, sebanyak 4 orang (20\%) kategori rendah, nilai C sebanyak 2 orang $(10 \%)$ kategori rendah, nilai D 2 orang(10\%) kategori rendah. Pada siklus II, yang mendapatkan nilai "A" sebesar 15 orqng(75\%) kategori tinggi, dan yang mendapatkan nilai "B" sebanyak 5 orang(25\%) kategori rendah.

Melihat hasil belajar siswa di atas, setelah diterapkannya perangkat pembelajaran berbasis nilai moral, dimana pada ujicoba II tidak ada mahasiswa memperolah nilai "C", hal disebabkan karena proses pembelajaran dengan menerapakan perangkat pembelajaran berbasis nilai moral telah menjadikan pembelajaran lebih bermakna. Proses pembelajaran telah mampu menjadikan siswa menjadi aktif. Peserta didik dapat merasakan makna dari pelajaran yang mereka pelajari. Pelajaran akan mudah dipahami oleh peserta didik jika mereka dapat merasakan makna dari materi pelajaran tersebut. Pembelajaran dengan memberikan pengalaman secara langsung kepada siswa membantu dosen dalam melaksanakan kegiatan pembelajaran sehingga siswa terlibat secara aktif dan menemukan makna dari materi yang mereka pelajari. Didukung oleh pendapat Nurhadi dkk, bahwa 
pengetahuan yang bermakna diperoleh dari proses. Pengetahuan yang dimiliki siswa diperluas melalui konteks pembelajaran, yang kemudian diperluas sedikit demi sedikit dengan membuat hubungan-hubungan antara pengetahuan yang dimiliki sebelumnya dengan pengetahuan yang baru.

Ada berbagai macam penilaian yang digunakan untuk melihat perkembanagan yang diserap oleh siswa. Misalanya Ujian Tengan Semester (UAS), Ujian Akhir Semester (UAS), atau dengan pemberian soal-soal yang dijawab secara tertulis maupun non tertulis. Jadi pemberian tes merupakan salah satu cara untuk melihat perkembanagan kognitif yang diserap oleh siswa sedangkan penilaian afeksi dilakukan dengan mengamati serangkaian sikap siswa. Sahlan dkk mengatan bahawa penilaian afektif dapat diperoleh guru melalui serangkaian sikap yang diperlihatkan oleh siswa, baik sikap dalam siswa dalam kelas maupun di luar kelas seperti disiplin, menjaga ketertiban dan kebersihan kelas, bertanggung jawab dalam menyelesaikan tugas, tidak menyontek waktu ujian, dan sebaginya.

\section{PENUTUP}

\section{Kesimpulan}

Melihat hasil temun pada Ujicoba I dan II seperti yang telah disajikan di atas maka dapat disimpulkan bahwa, berdasarkan hasil penilaian 3 orang validator menunjukan bahwa, perangkat pembelajaran yang telah dikembangkan memiliki kualitas baik, sehingga layak untuk digunakan dalam pembelajaran. Penerapan perangkat pembelajaran yang telah dikembangkan, berdasarkan hasil temuan di atas adalah efektif, hal di didasri oleh beberapa aspek yaitu, RPP telah terlaksana dengan dengan sangat baik, kecuali pada kegitan inti pada kegiatan Ujicoba I yang dilakukan dengan baik, mahasiswa aktif selama pembelajaran, mahasiswa memiliki minat dan motivasi yang poitif/baik selama pembelajaran, dan hasil belajar siswa, di atas 85\% sudah mencapai ketuntasan. 


\section{Saran}

Beberapa saran dari hasil penelitian yang telah dilakukan ini adalah.

a. Dalam mengembangkan perangkat pembelajaran, terutama BAM, LKS, dan THB hendaknya menggunakan bahasa atau istilah yang mudah dimengerti oleh mahasiswa atau bahasa yang tidak menimbulkan penafsiran ganda oleh mahasiswa, dan menyajikan contoh-contoh yang memadai yang sudah dikenali oleh mahasiswa dari lingkungan hidupnya.

b. Hendaknya dilakukan penelitian lanjutan mengenai faktorfaktor laian yang mempengaruhi hasil belajarmahasiswa, selain model pembelajaran misalnya factor ekonomi, factor asal mahasiswa.

\section{DAFTAR PUSTAKA}

Crain, W.C. 1985. Kohlberg'ws Stages of Moral Development".Diakses melalui http://psychology. about.com/od/develpmentalpsychology/kohlberg.htm pada tangga 15 November 2013. Waktu 20.25 WITA

Depdiknas. 2003. UU RI No. 20 Tahun 2003 tentang Sistem Pendidikan nasional.

El Mubarok Zaim. 2008. Membumikan Pendidikan Nilai. Mengumpilkan yang Terserak, Menegembangkan yang Terputus dan Menyatukan yang Tercerai. Bandung: Alfabeta.

Habibi. 2009. “ Pengembanagan Perangkat Pembelajaran Biologl SMA Berorientasi pada Model Pembelajaran Pemaknaan untuk Mengajarkan Kemampuan Akademik dan Sensitivitas Moral Mahasiswa". Tesis Magister. Universitas Neheri Surabaya.

Indrawati, 2004. Model Pembelajaran Konstruktivisme. Modul Diklat Berjenjang, P3G IPA.

Isjoni, 2009. Pembelajaran Kooperatif Meningkatkan Kecerdasan Komunikasi Antar Peserta Didik(Yogyakarta:Pustaka Pelajar.

144 BIOTA: Jurnal Tadris IPA Biologi FITK IAIN Mataram 
Irzani, 2009. Strategi Belajar Mengajar Matematika. Yogyakarta: Media Grafindo Press.

Khadijah, 2006. "Pemanfaatan Peta Konsep Untuk Meningkatkan Taraf Serap dan Motivasi Belajar Siswa Pada Mata Pelajaran IPA di kelas V SDN Nomor 27 Ampenan Tahun Ajaran 2005/2006". Skripsi. Mataram: IKIP Mataram.

Kunandar, Guru Professional Impelementasi Kurikulum Tingkat Satuan Pendidikan (KTSP) Dan Persiapan Menghadapi Sertifikasi Guru(Jakarta: PT Raja Grafindo Persada

Muslimin Ibrahim dkk, 2000.Pembelajaran kooperatif. Surabaya: Unesa University Press.

Mulyaningsih, S. 1999. Pengembangan Penuntun Belajar dengan Peta Konsep untuk Meningkatkan Pemahaman Konsep IPA di Sekolah Dasar. Jurnal Riset. No. 10/Th. V, p 1-9.

Nur, M. 1998. "Pengembangn Perangkat Pembelajaran dalam Rangka Menunjang Implementasi Kurikulum IPA 1994 di Indonesia".Makalah yang Disampaikan pada Improving Teaching Proficiency of Indonesia Junior and Senior Secondary Science Teachers di SEAMEO-RESCAM, Penang, Malaysia.

Nurhadi, Yasin, B., \& Senduk, A.G. 2004. Pembelajaran Kontekstual dan Penerapannya dalam KBK. Malang: Universitas Negeri Malang.

Rest, James. 1995. "The Four Component of Acting Moral" dalam Kurtines, W.M. dan Gerwitz, J.L. Moral Development, an Introduction. Needhan Height: A Simons dan Schuster Company.

Sumaji. 1998. "Dimensi Pendidikan IPA dan Pengembangan sebagai Disiplin Ilmu. Dalam Pendidikan Sains yang Humanistis. Yogyakarta: Kanisius.

Sagala. 2003. Konsep Dan Makna Pembelajaran. Bandung: Alfabeta.

Sahlan dkk. Desain Pembelajaran Berbasis Pendidikan Karakter.Yogyakarta:AR-RUZZ MEDIA. 2012.

Sudirman, N. 1991. Ilmu Pendidikan. Bandung: Remaja Rosdakarya. 
Sarkin.1998 "Humaniora dalam Pendidikan Sains".Dalam Pendidikan Sains yang Humanistis. Yogyakarta: Kanisius Trianto.2009. Mendesain Model Pembelajaran Inovatif Progresif. Jakarta: Kencana Prenada Media Group

Wong Muba melalui http://wangmuba.com/2009/02/16/teoriperkembangan-moral-piaget/) Diakses 15 November 2013.Waktu 20.25 WITA 